\title{
Plants as Natural Dyes for Jonegoroan Batik Processing in Jono Cultural Tourism Village, Bojonegoro, East Java
}

\author{
Nurizza Fauziyah ${ }^{*}$, Luchman Hakim \\ Department of Biology, Faculty of Mathematics and Natural Sciences, University of Brawijaya, Malang, Indonesia
}

\section{Abstract}

Batik Jonegoroan is one of the potential tourism product in Jono Village, Bojonegoro. Batik was processed by traditional procedure using natural dyes from plants. In order to preserve the traditional batik which was colored by natural dyes from plant, the preservation of such plant were important. As far, there are no scientific data related to the species usage in Batik production. The aims of the research were identifying plant which were used as natural dyes in Batik processing. Data were collected through observation, and semi-structured interviews to batik craftsmen. Results of interviews were analyzed descriptively. The importance of plant was analyzed using Relative Frequency of Citation (RFC) index. Based on the results, there are 12 plant species used as batik dye. It is consisted of Teak, Mahogany, Ketapang, Tamarind, Mangosteen, Mango, Suji, Pandan, Indigofera, Guava, Banana and Onion. Teak (Tectonagrandis L.) and Mahogany (Swietenia mahogany L.) have the highest value of RFC, 1.00. Both species were the most frequently cited species as sources of natural dyes. Extraction of Teak leaves produce red hearts and extraction of mahogany tree bark produces red-brown dye. Both of the color is the most important color in batik motifs.

Keywords: batik Jonegoroan, Jono Cultural Tourism Village, perception, quality, RFC

\section{INTRODUCTION}

The uses of plants as natural dyes have been widely reported. In Indonesia, it has been reported commonly among Batik traditional home industry in Java. Batik is traditional textile originally from Java Island. Batik is one of the cultural heritages of Indonesia. Batik is a traditional dyeing technique using wax to create special patterns on textile. Batik is common among Javanese society and become the social and cultural identity [1]. Batik motifs and pattern are very diverse. Every region in Indonesia has a certain batik style in accordance with the characteristics and potential of the local area. Flora-fauna-base motifs were common in batik. These diverse motifs represent the Javanese perception about flora-fauna diversity. Jonegoroan is a typical batik from Bojonegoro, East Java with numerous motifs. Recently, new motif has been introduced to the local home industry. These new motifs gets big enthusiast from Bojonegoro society.

Increase of batik needs in Indonesia led to numerous factory and home industry produce batik intensively. These phenomena lead to the use of technology and chemical dyes to produce Batik [2]. One of recent technological involvement in Batik industry is synthetic dye. Batik

\footnotetext{
${ }^{*}$ Correspondence address:

Nurizza Fauziyah

Email : crayonbiruku@gmail.com

Address : Dept. of Biology, University of Brawijaya JL. Veteran Malang, 65145
}

Industrial reports confirm that most of the batik craftsmen in Java prefer to use synthetic dyes to produce batik. The craftsmen prefer to use synthetic dyes in order to produce batik due to its economical benefits. Using synthetics dyes will allowing large quantities, short time, and low cost of Batiks processing. The cost of production of batik cloth with synthetic dyes is relatively low. Craftsmen have perception that the low price of batik with synthetic dye will be able to increase purchasing of the batik cloth.

There are few attention and research in the uses of natural dyes from plant as natural dyes. However, some community member in Jono Villages use plants as natural dyes in batik processing. These allow more sustainable practices which are important in green and ecoproduct, including Batik. Based on these descripttions, it is necessary to investigate what types of plants are used as natural dye in batik production.

\section{MATERIALS AND METHODS}

Data collection in this study included interviews, observation, documentation, and full participation in Jono Cultural Tourism Village, Temayang, Bojonegoro. Semi-structured interviews were implemented to identify the diversity of plants species which were used as natural dyes and its processing. Informants were selected by purposive sampling. Interview material includes several points, including name of species, plant's parts used, processing, and the resulting color. 
The data of plants usage were analyzed using Relative Frequency of Citation (RFC) as one of the significant ethnobotanical indices. The value was obtained by dividing the number of respondents who mentioned a plant species which is beneficial (FC) with the number of informants who participated in the survey $(\mathrm{N})$ [3].

$$
R F C=\frac{F C}{N}
$$

\section{RESULTS AND DISCUSSION}

The craftsmen get the natural dyes material from home garden and sometimes were bought from nearest market. Some plants were very easy to collect, such as Teak, Mango, pandan leaf, guava and mahagoni. Mango, pandan and guava grow in home garden or area adjacent to the house. Teak was often cultivated in homegarden, or the leaf was collected from teak plantation. In Jono Village, the important species which were used as natural dyeing were Teak, Mahogany, Ketapang, Tamarind, Mangosteen, Mango, Suji, Pandan, Indigofera, Guava, Banana, and Onion (Table 1). In traditional batik processing, leaves and bark commonly used as the sources of natural dye. These materials provide numerous colors which are needed in batik drawing.

Teak and mahogany has the highest RFC value (1.00). Both species mentioned by the entire respondent as an important plant which intensively used as natural dye. These materials can be collected easily from home garden, forest, and plantation. Extraction of teak leaves produce red hearts colour in textile. Meanwhile, Mahogany tree bark extraction produce yield red-brown color.

The fresh leaves were collected from home garden and plantation as natural dye. The preparation of natural dye were reported simple. First, the leaves are cut in size of $\pm 8 \mathrm{~cm}$, washed, and extracted. The extraction of teak leaves produce red hearts color (Figure 1a). Young teak leaf contains several compounds, especially anthocyanin pigments. This anthocyanin compound gives red, purple, dark red [4]. The results of teak leaf extract is also used as a dye for yarn woll by the community of West Bengal, India [5].

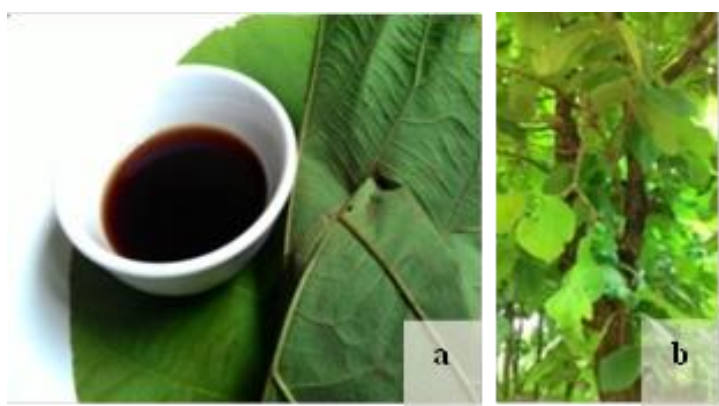

Figure 1. Jati (Tectona grandis): (a) the result of leaf extraction; (b) tree

The bark of Mahagony was used natural dye. The extraction of mahogany bark produce brownish red-brown color (Figure 2a). The extract of Mahogany tree bark can be used to color the wood [6]. The extract is also used as a dye in the leather tanning process.

Table 1. Natural dye plants in batik production

\begin{tabular}{|c|c|c|c|c|c|c|}
\hline No & Name of the species & Local name & Family & $\begin{array}{c}\text { Plants part(s) } \\
\text { which used as } \\
\text { dyeing }\end{array}$ & The resulting color & RFC \\
\hline 1 & Tectona grandis L.f. & Teak & Verbenaceae & Leaves & Red hearts & 1.00 \\
\hline 2 & Swietenia mahagoni (L.) Jacq. & Mahogany & Meliaceae & Bark & Red-Brown & 1.00 \\
\hline 3 & Terminalia catappa L. & Ketapang & Combretacea & Leaves & Yellow-gray & 0.89 \\
\hline 4 & Tamarindus indica L. & Tamarind & Fabaceae & Leaves & Greenish yellow & 0.78 \\
\hline 5 & Garcinia mangostana L. & Mangosteen & Clusiaceae & Rind & Magenta & 0.72 \\
\hline 6 & Mangifera indica $\mathrm{L}$. & Mango & Anacaridaceae & Leaves & Yellow & 0.56 \\
\hline 7 & Pleomele angustifolia N.E.Brown & Suji & Ruscaceae & Leaves & Light green & 0.50 \\
\hline 8 & Pandanus amaryllifolius Roxb. & Pandan & Pandanaceae & Leaves & Light green & 0.50 \\
\hline 9 & Indigofera sumatrana Gaertn & Indigofera & Fabaceae & Leaves & Blue & 0.50 \\
\hline 10 & Psidium guajava $\mathrm{L}$. & Guava & Myrtaceae & Leaves & Yellowish-brown & 0.50 \\
\hline 11 & Musa paradisiaca L. & Banana & Musaceae & leaf sheath & Brown & 0.50 \\
\hline 12 & Allium cepa $\mathrm{L}$. & Onion & Liliaceae & Bulbs & Red-brown & 0.39 \\
\hline
\end{tabular}


The uses of mahagony as natural dye were common among society in developing countries. Bangladeshi society accustomed to using the extraction of mahogany tree bark as a natural dye for textiles [7]. In Bojonegoro, the craftsmen get part of the plant from garden and forest.

Onion (shallot or red onion) has the lowest RFC values (0.39) indicated that the species is less used by society in Jono Villages as natural dye. Few respondent know about the natural dye which was produced from onion. However, onion is one of the important materials for food processing. Onion has economic value, and in particular season the prices was very high. Craftsmen who use extraction from onion bulbs get the bulbs from traditional market.
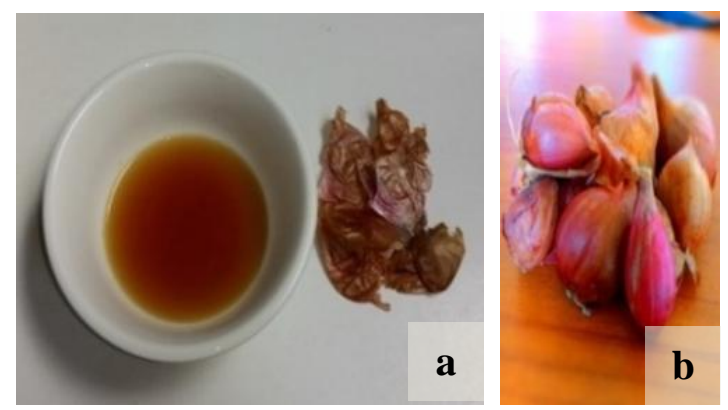

Figure 3. Onion (Allium cepa): (a) the result of onion bulbs ekstraction; (b) onion bulbs

Natural dye from plant species need to be introduced to the public. It is especially important in order to introduce the value of plants in society, especially in Batik processing. The uses of natural dye will support the ecoindustrial development in rural area. In such case, efforts to introduce natural dye from Batik can be done in several ways such as:

1. Learn the benefits of natural plant dye.

Knowledge about the benefits of the plant is expected to raise public awareness on the importance of efforts to maintain and preserve it. This knowledge can be obtained through direct explanation to the public and environmental education in the formal and non-formal school.

2. Using the natural plant dye - batik.

Utilizing the natural dyed batik would make people get the utilizing of natural dye plants directly. If people have felt the direct usefulness, then the existence of a natural plant dye batik will always be needed. Utilization of these plants should be done wisely and sustainably thus the benefit of the plant can be felt continuously by the community.

3. Cultivating the natural dye plants.

Protecting batik natural dye plant can be done by planting, and cultivating plants which were producing natural dye. People can cultivate these plants in the yard of their home. The more people who grow and cultivate the plants, the easier they get these plants.

Natural dye plant conservation efforts not only the duty of the public but also the government. Bojonegoro government has a role in conservation of natural plants which were important in natural dye product. The development of Batik which was processed using natural dye will support Jono as a Cultural Tourism Village Jono, which become creative industries in Bojonegoro.

There are opportunities for natural plant conservation to enhance the sustainability of natural dyes resources. Home gardens in Jono Village can be potential spot to cultivate numerous plant species which area important as natural dyes. Worldwide, home garden has been considered important to support human life in rural environment. Home garden contributes significantly to support community's heath, food security program and tourism. There are also opportunities for home garden to support sustainability of natural dyes for home industry of Batik.

\section{CONCLUSION}

There are 12 plant species used as dye for batik, i.e. Teak, Mahogany, Ketapang, Tamarind, Mangosteen, Mango, Suji, Pandan, Indigofera, Guava, Banana and Onion. Teak (Tectona grandis L.) and mahogany (Swietenia mahogany L.) have the highest value of 1.00 RFC. These species is the most frequently cited by respondents. Craftsmen in Jono village already know and use both of these plants for batik dyeing. Natural dye plant species need to be introduced to the public so that they know the additional benefits of the plants.

Recognition efforts can be done in several ways, such as studying the benefits of batik natural dye plant. We could also using natural dyed batik wisely and sustainably so that the benefits of the plants can be perceived by the public. Last, we could protect batik natural dye plant by planting, tending, and cultivating them. The use of natural dyes is also an attempt to reduce the use of synthetic dyes. 


\section{REFERENCES}

[1] Nurdalia, I. 2006. Kajian dan analisis peluang penerapan produksi bersih pada usaha kecil batik cap. Master Thesis. Uniersity of Diponegoro.

[2] Sangsoko, D. 2010. Identifikasi unsur dan kadar logam berat pada limbah pewarna batik dengan metode analisis pengaktifan neutron. Jurnal IImu Pengetahuan dan Teknologi 27 (1)

[3] Tardio, J. and M. Pardo-De-Satayana 2008. Cultural Importance Indices: a comparative analysis based on the useful wild plants of southern Cantabria (Norhern Spain). Economic Botany 62 (1), 24-39.

[4] Kembaren, R., S. Putriliniar, N. Maulana, R. Ikono, and N. Rochman. 2013. Ekstraksi dan karakteristik serbuk nano pigmen dari daun tanaman Jati (Tectona grandis linn. F). Proceeding of Semirata. FMIPA, University of Lampung.

[5] TIES. 2000. Ecotourism statistical fact sheet. The International Ecotourism Society.

[6] Boo, E. 1990. Ecotourism: the potential and pitfalls (2 Vols). World Wildlife Fund, Baltimore.

[7] Lascurian, C. 1996. Tourism ecotourism and protected areas. Papers of Tourism Workshops. The World Congress IV on National Park and Protected Areas. Caracas, Venuzuela. 